\title{
Variability of Transferrin in Field Mice from an Urban Park, Suburban Island and Field Populations ${ }^{x}$
}

\author{
Anna DOBROWOLSKA \& Ludmiła WOLANSSKA
}

Dobrowolska A. \& Wolańska L., 1985: Variability of transferrin in field mice from an urban park, suburban island and field populations. Acta theriol., 30, 21: 327-335 [With 2 Tables]

Studies were made on Apodemus agrarius inhabiting three different urban and suburban environments. Statistically significant seasonal differences in transferrin allele frequencies were observed only in the field population. The greater number of heterozygotes in the island population than in the others in spring was followed by large numbers of mice there in autumn. Smaller variability in Trf locus was observed in the more differentiated and richer environment (farmland). The greatest variation was found in mice from the urban isolated park, due mainly to high frequencies of the rare slow alleles $T r f^{c}$ occurring in males. The role of males in the adaptation of a field mouse population to an urban environment by the maintenance of transferrin polymorphism is suggested. The physiological consequences of the "ferrum poor" transferrin (Trfc) occurrence in males as well as in females are discussed, and the greater survival rate of the $\operatorname{Tr} f^{c}$ allele individuals in urban population is postulated. The conclusion is that the adaptation of field mice to urban conditions may take place in the range of polymorphic forms found in this species. Selection operating there may prefer rare genotypes in a typical field population to a greater degree than in a non-urban isolated population (island). Better survival and probably the lower fertility of these genotypes may result in different numbers in an urban population in comparison to other natural field mouse populations.

[Dept. Vertebr. Anim. Physiol., Inst. of Zool., Univ. of Warsaw, Zwirki i Wigury, 93, 02-089 Warszawa, Poland; Inst. of Biol. Bases of Anim. Prod., Acad. of Agriculture, Cybulskiego 20, 50-205 Wroclaw, Poland]

\section{INTRODUCTION}

The expansion of Apodemus agrarius, a field rodent, towards urban environments may be evidence of microevolutionary processes, and it would therefore seem important to make studies of the variability of its populations in urban and suburban areas. The questions are: (a) Is a population inhabiting an urban area composed of individuals genetically different from those living in a typical field environment or do they represent the same forms in the range of polymorphism found in a field population but in different proportions?; (b) What are the re-

${ }_{1}$ Praca wykonana w ramach problemu MR.II.6, koordynowanego przez Zakład Paleobiologii PAN. 
lations between the genetic pattern and resulting numbers observed in the urban and suburban populations?

The city of Wrockaw and its suburbs formed the area for research on tranferrin polymorphism in field mouse populations. The animals from an isolated urban park population were compared with animals from an isolated non-urban populations (suburban island) and with those from a typical field population (suburban farmland). It was assumed that comparison of the populations from the isolated areas with a similar vegetation unit, one in an urban area, and the other field population, would permit of distinguishing between the differences arising from isolation on the one hand and from the influence of urban conditions on the other.

\section{MATERIALS AND METHODS}

The field mice were trapped in spring (May-June) and in autumn (September-October) for two years (1977-1978). The study areas were: (a) The Szczytnice Park in the northern part of Wroclaw city, frequently visited by people and surrounded by densely built up streets with heavy traffic (one side was open for migration). This area is characterised by differentiated vegetation (17 species of trees and bushes, herb layer plants); (b). The island in the Odra river (Opatowice Island) situated in the eastern suburbs of Wroclaw city, formed in $1902 / 1903$, connected with the mainland by a foot-bridge (on the north) and by a sluice (on the south), 64 ha in area, with differentiated vegetation composed of 15 species of trees and bushes (in the north) and with glade flora (southern part of $16 \mathrm{ha}$ ). The island is periodically flooded and A. agrarius reaches its greatest numbers there in comparison with the other places examined; (c) fields (near Domasław village) $10 \mathrm{~km}$ away from Wroclaw. The field mice were caught there in an open area, not isolated, a considerable distance from the village. This area constituted an agrocenosis formed by a mozaic of farmlands (rape, wheat, pasture-mixture), within which the field mice were able to migrate.

Blood was taken from the retroorbital plexus under ether anaesthesia. The serum was stored at $-20^{\circ} \mathrm{C}$ until analysis. Separation of serum transferrin was carried out by means of starch gel electrophoresis (Tomaszewska-Guszkiewicz et al., 1971) using the Mueller et al. (1962) method (staining with nitroso-R salt) for identification of transferrin. Two alleles of single $\operatorname{Trf}$ locus $T r f^{a / b}$ and $T r f^{c}$ were distinguished. Interpretation of transferrin allelomorphs in Apodemus agrarius has been discussed by Dobrowolska et al. (1983).

Statistical analysis of the result was made with the chi-square test used by Gaines \& Krebs (1971), accepting the differences as statistically significant (S) at $p<0.05$.

\section{RESULTS AND DISCUSSION}

\subsection{Sex Differences}

A greater number of males than females was caught, especially in spring (Table 1). The numerical dominance of males, especially during 
the reproduction period, has been described earlier in a natural field mouse populations (Andrzejewski \& Włocławek, 1961; Haitlinger, 1962; Andrzejewski, 1963; Pelikan, 1965; Adamczewska-Andrzejewska, 1973), probably due to the greater mortality of females during both winter and summer reproduction (Andrzejewski et al., 1978). In spite of the similar sex ratio in the populations studied, stable sex differences in transferrin allele frequencies were not found (Table 1). Absence of such

Table 1

Frequencies of $\mathrm{Trf}^{a / b}$ allele in Apodemus agrarius from different urban and suburban environments.

\begin{tabular}{|c|c|c|c|c|c|}
\hline \multirow{2}{*}{ Study area } & & \multicolumn{2}{|c|}{1977} & \multicolumn{2}{|c|}{1978} \\
\hline & & Spring & Autumn & Spring & Autumn \\
\hline Fields & $\begin{array}{c}\text { M } \\
\text { F }\end{array}$ & $\begin{array}{l}0.909^{1} \\
(11) \\
0.909^{2} \\
(11)\end{array}$ & $\begin{array}{l}0.961^{1,3} \\
(26) \\
1.000^{2} \\
(20)\end{array}$ & $\begin{array}{l}1.000 \\
(3) \\
0.857^{6} \\
(7)\end{array}$ & $\begin{array}{l}0.982 \\
(28) \\
0.967^{\circ} \\
(31)\end{array}$ \\
\hline Island & $\begin{array}{l}\text { M } \\
\text { F }\end{array}$ & $\begin{array}{c}0.937 \\
(8) \\
0.875 \\
(4)\end{array}$ & $\begin{array}{l}0.895^{3,4} \\
(24) \\
0.923^{5} \\
(23)\end{array}$ & - & $\begin{array}{l}0.943 \\
(35) \\
0.973^{7} \\
(29)\end{array}$ \\
\hline Urban Park & $\begin{array}{l}\mathrm{M} \\
\mathrm{F}\end{array}$ & $\begin{array}{c}- \\
0.660 \\
(2)\end{array}$ & $\begin{array}{l}0.689^{4} \\
(8) \\
0.800^{5} \\
(10)\end{array}$ & $\begin{array}{l}0.909 \\
(22) \\
0.893 \\
(14)\end{array}$ & $\begin{array}{c}- \\
0.888^{7} \\
(9)\end{array}$ \\
\hline
\end{tabular}

M - males, F - females; pairs of numbers=differences statistically significant at $p<0.05$; in brackets $=$ number of samples.

differences is similar to the results obtained for field mice from Warsaw (Dobrowolska et al., 1983) and the results obtained for many other species of mouse (i.e. cited authors). In one season, however, the same sex dependences in Trf allele frequencies were found in all areas (in females $\operatorname{Tr} f^{a / b}$ frequencies were lower in spring and higher in autumn, Table 1). This seems to be resulted by selection synchronised by seasonal environmental conditions independently of the character of population (isolated, non-isolated; urban, suburban).

In the material studied the rare homozygotes $\operatorname{Trf} / \mathrm{Tr} \mathrm{f}^{\mathrm{c}}$ were found mainly in males (Table 2). This fact may suggest the possibility of a different selection in Trf locus in both sexes (with a preference of the slow band of transferrin $T r f^{c}$ in males). The slow band (less saturated by ferrum, after Mueller et al. staining) is always accepted as $a$ band of transferrin binding only one atom of ferrum per molecule (Konopka, 1970). Hence it is possible that only in summer (when erythropoesis is dominated by leucocytosis - Rewkiewicz-Dziarska, 
1975; Rewkiewicz-Dziarska et al., 1977) males with lower capability of ferrum transport may survive. On the contrary, only females possessing the fast allele $\operatorname{Tr} f^{a / b}$, which is probably richer in ferrum, and especially pregnant females needing more ferrum in this physiological stage, could survive (Table 1). In general male mice and male voles with faster Trf allele had a higher survival rate than those with slower alleles (Gaines et al., 1978 and cited authors).

\subsection{Seasonal Changes}

When seasonal differences in frequencies of transferrin alleles were statistically significant they showed an increase in frequencies of common alleles from spring to autumn (Table 1) and were found in the field population, which inhabited the most natural environments occupied by the species studied. In females this increase took place mainly as a result of a fall in heterozygote numbers. This trend to a decrease of heterozygotes in autumn in field mice from the Wroclaw area is similar to the seasonal selection trend observed in the population of field mice also from the southern region of Poland (Lower Silesia) (Dobrowolska \& Zajączkowski, 1983). In monoculture fields there the populations seems to be more panmictic with regard to the occurrences of a greater number of heterozygotes in late summer and also in autumn.

In males caught on the Island and in the Park in the autumn of 1977 decrease in common allele, with increase of the rare homozygotes $\operatorname{Tr} f^{c} / \operatorname{Trf}{ }^{c}$, was observed, especially in the urban park (Table 1, 2). It may be assumed that in these isolated populations $\mathrm{Trf}^{c}$ homozygotic males may survive better from summer to autumn, and the better viability of the homozygotic males may enrich the pool of genes in the isolated areas.

\subsection{Population Differences}

Genotypic representation showed agreement with the Hardy-Weinberg equilibrium (chi-square $<3.84$ ) in all the places studied.

Is la $\mathrm{nd}$ : The highest rate of increase in the numbers of field mice from spring to autumn on the island was accompanied by greater decrease in the heterozygote proportion from spring to autumn (Table 2). It is possible that the highest number of $\operatorname{Trf}$ heterozygotes on the island in comparison with other places in spring may influence the higher rate of increase in population numbers. Many authors have emphasized that natural selection must affect the increase in heterozygosity occurring in an isolated island population (Berry \& Murphy, 1969, Tamarin, 1978; and others). 
Urban Park: The rare homozygotes $\operatorname{Trf} f^{c} / \operatorname{Trf}^{c}$ were most frequently observed in a wide area with isolation (Table 1). Fraction $a$ from the system of bands $\operatorname{Tr} f^{a / b}$ was sometimes divided into two subtractions ( $8 \%$ in the group studied) occurring especially in sexually active males and pregnant females. Proportions of the subfractions, however, did not justify interpretation as a three allelic system of Trf locus $\left(\operatorname{Tr} f_{1}^{a} 1_{2}^{a}\right)$. This kind of "microheterogeneity" in transferrins was noted especially in microtines rodents (Biggers \& Dawson, 1971; Griswold \& Dawson, 1971; Gulyaeva \& Olenev, 1979, Eicher et al., 1980; Dobrowolska, 1981; cited by Mihok \& Ewing, 1983) but a background of this event was not determined yet (Mihok \& Ewing, 1983).

A relatively similar number of heterozygotes $\operatorname{Tr} f^{a / b} / \operatorname{Tr} f^{c}$ occurred from season to season and the differences in frequencies of alleles were caused by a high number of rare homozygotes $\operatorname{Trf} f^{c} / \mathrm{Tr} f^{c}$. Although heterozygote prevalence is usually responsible for maintenance of potymorphism in rodents (Gaines et al., 1978; and others), under the specific conditions of the isolated urban park rare homozygotes could play an important role.

The lack of stable seasonal differences in the numbers of urban park mice (Wolanska, in press) suggested the absence of an annual popufation cycle. The small and stable number might have been influenced by the greater impact of human activity and the greater number of predators, mainly cats, in this area. As these two factors were not determined there, only the genetic pattern can be correlated with the numbers occurring. It seems that the greater stability of the numbers of the urban park population may result from higher variability of transferrin locus (higher number of rare transferrin allele animals which have probably lower survival rate and fertility), hence these results are in agreement with others obtained for rodents (Anderson, 1970; Krebs, 1979; and later statements).

Field: In this population no great differences were observed in numbers of mice from year to year. This situation is similar to the one frequently found in natural Apodemus agrarius populations (Volkov et al., 1979; Adamczyk et al., 1983). The lowest variability in transferrin was found with the highest total number of individuals during the study period (in comparison with other populations). The differences in $\operatorname{Trf}$ locus in this open population from those in the mosaic of fields of different crops outside Wrockaw were lower in comparison with field populations from the smaller differentiated farmland (pasture-mixture, wintercorn) (Dobrowolska \& Zajączkowski, 1983). It may be concluded that Apodemus agrarius showed greater differentiation in monoculture crops than in the environment with more varied vegetation. The va- 
riability in the protein studied in A. agrarius indicates that the more differentiated and richer the environment, the lesser the variability.

The low variability found for mice in the mosaic of fields was produced by a relatively small number of homo- and heterozygotes containing the rare slow allele $T r f^{c}$ (Table 2). If the slow alleles bind only one atom of ferrum, in comparison to the faster migrating zone $(a, b)$ which may bind two $\mathrm{Fe}$ atoms, the animals from fields may have better conditions for hemoglobin production. This can be confirmed by the occurrence of a greater amount of hemoglobin in homogenates of certain organs (kidney, liver, heart) of field animals than in those living in an urban population (Wolańska, unpubl. data).

Table 2

Seasonal differences in the number of transferrin genotypes in Apodemus agrarius from different urban and suburban populations.

\begin{tabular}{|c|c|c|c|c|c|c|c|}
\hline \multirow{2}{*}{$\begin{array}{l}\text { Study } \\
\text { area }\end{array}$} & & \multicolumn{3}{|c|}{ Spring } & \multicolumn{3}{|c|}{ Autumn } \\
\hline & & $\begin{array}{l}\text { Trfa/b/ } \\
\text { Trfa/b }\end{array}$ & $\begin{array}{l}T r f^{a / b /} \\
T r f^{c}\end{array}$ & $\begin{array}{l}T r f^{c /} \\
T r f^{c}\end{array}$ & $\begin{array}{l}\text { Trfa/b/ } \\
T r f^{a / b}\end{array}$ & $\underset{T r f^{a / b}}{\operatorname{Tr}}$ & $\begin{array}{l}\text { Trfel } \\
\text { Trfe }\end{array}$ \\
\hline Fields & $\begin{array}{l}\text { Obs. } \\
\text { Exp. }\end{array}$ & $\begin{array}{l}38 \\
38.08\end{array}$ & $\begin{array}{l}4 \\
3.38\end{array}$ & $\begin{array}{l}0 \\
0.54\end{array}$ & $\begin{array}{l}100 \\
100.06\end{array}$ & $\begin{array}{l}5 \\
5.05\end{array}$ & $\begin{array}{l}0 \\
0.02\end{array}$ \\
\hline Island & $\begin{array}{l}\text { Obs. } \\
\text { Exp. }\end{array}$ & $\begin{array}{l}10 \\
10.08\end{array}$ & $\begin{array}{l}2 \\
1.85\end{array}$ & $\begin{array}{l}0 \\
0.07\end{array}$ & $\begin{array}{l}92 \\
90.25\end{array}$ & $\begin{array}{l}6 \\
9.5\end{array}$ & $\begin{array}{l}2 \\
0.25\end{array}$ \\
\hline $\begin{array}{l}\text { Urban } \\
\text { Park }\end{array}$ & $\begin{array}{l}\text { Obs. } \\
\text { Exp. }\end{array}$ & $\begin{array}{l}30 \\
27.9\end{array}$ & $\begin{array}{l}5 \\
9.43\end{array}$ & $\begin{array}{l}3^{1} \\
0.77\end{array}$ & $\begin{array}{l}20 \\
16.33\end{array}$ & $\begin{array}{l}2 \\
9.32\end{array}$ & $\begin{array}{l}5^{1} \\
1.35\end{array}$ \\
\hline
\end{tabular}

1 Males.

It is interesting that the greatest frequency of rare Trf allelomorphs was found in an isolated population (urban park) of the smallest number of animals, while the lowest frequency occurred in a larger non-isolated population (open field). The above mentioned gradient of transferrin polymorphism is compatible with the gradient recorded in the same year (1977) in populations of field mice inhabiting the urban area of Warsaw, but it differs from the gradient found in Warsaw in preceding years $(1975,1976)$. The difficulty in interpretation of the variability found in relation to the isolation rate of the populations has existed since the studies by Berry and Murphy in 1969 on mice inhabiting an island (e.g. Berry, 1970; Rasmussen, 1970; Lidicker, 1973; Tamarin, 1978). The greater differentiation of an Apodemus agrarius population in an isolated area would appear to indicate adaptation to a habitat, according to opinions held by the authors cited. Apodemus agrarius is known to be a species which changes its habitat probably to search for suitable 
food as it changes from season to season (Haitlinger \& Korzeniowski, 1962; Holišova, 1967; Zejda, 1967; Adamczewska-Andrzejewska, 1973). In the isolated area it cannot change its habitat on account of limited opportunities for migration. It is possible that in such a situation this species may compensate its individual behavioural heterogeneity by a greater heterogeneity in genetic pattern.

It is well known that mice regulate population numbers by migration (Lidicker, 1976; Tamarin, 1978; and others). When migration is: limited of even impossible for an isolated population of field mice their variability seems to be supported by maintenence of the rare homozygotes. Taking into consideration the fact that a larger number of rare homozygotes occurs in male field mice from an isolated urban park population it may be concluded that there are males which may be of greater importance in the synurbization processes by the maintenance of Trf polymorphism.

Acknowledgements: Our thanks are due to Professor R. Andrzejewski and Dr $\mathrm{K}$. Adamczewska-Andrzejewska for discussion on the biology of Apodemus agrarius. We are very grateful to Assistent Professor M. Gebczyński for his criticism and valuable remarks during preparation of the manuscript.

\section{REFERENCES}

1. Adamczewska-Andrzejewska K., 1973: Growth, variation and age criteria in Apodemus agrarius (Pallas, 1771). Acta theriol., 19: 353-394.

2. Adamczyk K., Chelkowska H. \& Walkowa W., 1980: Studies of a rodent community in a forest environment of Silesia in the years 1977, 1978. Pol. ecol. Stud., 6: 763-773.

3. Anderson R. K., 1970: Ecological structure and gene flow in small mammals. Symp. zool. Soc. Lond., 26: 299-325.

4. Andrzejewski R. \& Wlocławek H., 1961: Mass occurrence of A. agrarius (Pallas, 1771) and variations in the number of associated Muridae. Acta theriol., 13: 173-184.

5. Andrzejewski R., 1963: Processes of incoming settlement and disappearence of individuals and variation in the number of small rodents. Acta theriol., 11: $169-213$.

6. Andrzejewski R., Babińska-Werka J., Gliwicz J. \& Goszczyński J. 1978: Synurbization processes in Apodemus agrarius population. I. Characteristics of populations in urbanization gradient. Acta theriol., 20: 341-358.

7. Berry R. J. \& Murphy H. M., 1979: The biochemical genetics of an isolated population of the house mouse. Proc. Roy. Soc. Lond., B, 176: 87-103.

8. Berry R. J., 1970: Covert and overt variation as exemplified by British mouse populations. Symp. zool. Soc. Lond., 26: 3-26.

9. Dobrowolska A., Jabłońska E., Patrzykont A. \& Chabros E., 1983: Variability of transferrin in field mouse from urban and suburban populations. Acta theriol., 28: 235-242.

10. Dobrowolska A. \& Zajączkowski M., 1983: Variability of transferrin in three species of rodent populations coexisting in farmland. Acta theriol, 28: 225-233. 
11. Gaines M. S. \& Krebs Ch. J., 1971: Genetic changes in fluctuating vole population. Evolution, 25: 702-723.

12. Gaines M. S., McClenaghan L. R. Jr \& Rose R., 1978: Temporal pattern of allozymic variation in fluctuating populations of Microtus ochrogaster. Evolution, 30: 723-739.

13. Haitlinger R., 1962: Morphological variability in Apodemus agrarius. Acta theriol., 6: 239-255.

14. Haitlinger R. \& Korzeniowski A., 1962: Badania ekologiczne drobnych ssaków na wybranym terenie w okolicy Wrocławia. Acta Univ. Wrat., Zool. 1: $35-54$.

15. Holišova V., 1967: The food of Apodemus agrarius (Pall.). Zool. Listy, 16: $1-14$.

16. Konopka K., 1970: Funkcja transferyny. Postępy Biochemii, 15: 205-220.

17. Krebs Ch. J., 1979: Dispersal spacing behaviour and genetics in relation to population fluctuations in the vole Microtus townsendii. Fortschr. Zool., 25: $61-77$.

18. Lidicker, W. Z., Jr 1973: Regulation of numbers in an island population of the California vole, a problem in community dynamics. Ecol. Monographs, 45: $271-302$.

19. Mihok S. \& Ewing D., 1983: Reliability of transferrin and leucin aminopeptidase phenotyping in wild meadow voles (Microtus pennsylvanicus). Biochem. Genet., 21: 969-983.

20. Mueller J. O., Smithies O. \& Irvin P. R., 1962: Transferrin variation in Columbidea. Genetics, 43: 1385-1392.

21. Pelikán J., 1965: Variability of body weight in three Apodemus species. Zool. Listy, 16: 199-220.

22. Rasmussen D. J., 1970: Biochemical polymorphism and genetic structure in population of Peromyscus. Symp. zool. Soc. Lond. 26: 335-349.

23. Rewkiewicz-Dziarska A., 1975: Seasonal changes in hemoglobin and erythrocyte indices in Microtus arvalis (Pallas, 1979). Bull. Acad. pol. Sci., Cl. II, 26: $337-342$.

24. Rewkiewicz-Dziarska A., Wielopolska A. \& Gill J., 1977: Hematological indices of Apodemus agrarius (Pallas, 1771) from different urban environments. Bull. Acad. pol. Sci., C1.II, 25: 263-270.

25. Tamarin P. H., 1978: Dispersal population regulation and K-selection in the field mice. Amer. Natur., 112: 546-555.

26. Tomaszewska-Guszkiewicz K., Składanowska E. \& Zurkowski M., 1971: Badanie nad polimorfizmem amylazy surowicy krwi bydła nizinnego czarno-bialego w Polsce. Biul. Inst. Genetyki i Hodowli Zwierząt PAN, 24: 5-10.

27. Volkov V. J., Chernych P. A., Dolgich A. M. \& Jakovleva T. V., 1979: Rasprostranenie i osnovnye čerty ekologii polevoj myši (Apodemus agrarius) in the Amur territory. Zool. Ž., 58: 1202-1212.

28. Zejda J., 1967: Habitat selection in Apodemus agrarius (Pallas, 1771), Mammalia, Muridea) on the board of the area of its distribution. Zool. Listy, 16: $15-30$.

Accepted, May 20, 1985. 
Anna DOBROwOLSKA i Ludmiła WOLAÑSKA

\section{ZMIENNOSC TRANSFERYN U MYSZY POLNEJ Z MIEJSKIEGO PARKU PODMIEJSKIEJ WYSPY I POLNEJ POPULACJI}

\section{Streszczenie}

Badania przeprowadzono na myszy polnej Apodemus agrarius zamieszkującej tereny zróżnicowane przestrzennie o różnym stopniu izolacji. W bardziej zróżnicowanym, bogatym środowisku (pola uprawne) obserwowano mniejsze zróżnicowanie w badanym locus (Table 1,2 ). Na wyspie większa liczba heterozygot obserwowanych wiosną poprzedzała dużą liczebność myszy jesienią (Table 2). Największą zmienność transferyn stwierdzono u osobników $\mathrm{z}$ izolowanego miejskiego parku (Table 1, 2). Pochodziła ona od wysokich częstości rzadkiego wolnego allelu Trfc występującego u samców (Table 2). Zasugerowano rolę samców myszy polnej w adaptacji populacji do warunków miejskich poprzez utrzymanie polimorfizmu. Przedyskutowano fizjologiczne konsekwencje występowania ubogiej w żelazo transferyny $\left(T r f^{c}\right)$ zarówno u samców jak i u samic. Postulowano mniejszą przeżywalność osobników z allelem $\operatorname{Trfc} \mathrm{z}$ populacji polnej. Wnioskowano, że adaptacja myszy polnej do warunków środowiska zurbanizowanego mogłaby dokonywać się w obrębie form polimorficznych znajdowanych u tego gatunku. Działająca tam selekcja preferowałaby genotypy rzadko występujące w typowej polnej populacji, a inna ich przeżywalność dawałaby różną liczebność miejskiej populacji w stosunku do innych naturalnych populacji. 